\title{
INTERAKSI SIMBOLIK PRIA METROSEKSUAL (STUDI FENOMENOLOGIS PADA FRONTLINER PT BANK CENTRAL ASIA KCU GADING SERPONG TANGERANG)
}

\author{
Faisal Tomi Saputra, Doni Gunawan \\ ftsaputra@unis.ac.id \\ Program Studi Ilmu Komunikasi, Fakultas Ilmu Sosial dan Ilmu Politik, \\ Universitas Islam Syekh Yusuf Tangerang, Indonesia 15118
}

\begin{abstract}
ABSTRAK
Fenomena pria metroseksual merupakan sebuah fenomena sosial yang saat ini mulai banyak dan tersebar di Indonesia, tidak terkecuali di Kota Tangerang. Gaya hidup metroseksual memiliki karakteristik unik dan sangat memperhatikan penampilan melebihi kaum wanita dan masih dipandang sebelah mata oleh sebagian masyarakat. Penelitian ini menggunakan teori interaksionisme simbolik Herbert Blummer yaitu Meaning, Language, Thought. Adapun objek penelitian ini adalah pria metroseksual pada sosok Frontliner di PT Bank Central Asia KCU Gading Serpong Tangerang yang ditentukan berdasarkan ciri-ciri pria metroseksual. Tipe penelitian ini bersifat deskriptif kualitatif. Hasil penelitian Pria Metroseksual pada sosok frontliner memiliki konsep dirinya sendiri, memperhatikan tata bahasa dalam berkomunikasi, menggunakan komunikasi verbal dan non verbal. Kepribadian yang dimiliki oleh pria metroseksual pada sosok frontliner menunjukan kepribadian yang sangat rapih dan teratur, terlihat dalam penampilan, sikap terhadap orang lain dan rasa bersahabat yang selalu ditunjukan kepada setiap orang.
\end{abstract}

Kata kunci: Interaksi Simbolik, Pria Metroseksual, Frontliner

\section{ABSTRACT}

The phenomenon of man metrosexual is a social phenomenon which is currently became too much and spread across indonesia, no exception in tangerang.Lifestyle metrosexual having the characteristics unique and very attentive to the appearance of more than women and Still considered under estimated by some communities. This study uses the theory of symbolic interactionism by Herbert Blummer is Meaning, Language, Thought. The object of this research is the metrosexual men in the figure of Frontliner at PT Bank Central Asia KCU Gading Serpong Tangerang, which is determined based on the characteristics of metrosexual men. This type of research is descriptive qualitative. The results showed the Metrosexual Male self-concept in frontliner figure has a concept of himself. Metrosexual men in frontliner figures interact with attention to grammar in communication, metrosexual men in frontliner figures pay attention to the use of verbal and non verbal communication. The personality of the metrosexual men in the frontliner figure shows a very regulated personality, seen in appearance, attitude towards others and a sense of friendliness that is always shown to everyone.

Keywords: Symbolic Interaction, Metrosexual Men, Frontliners.

\section{Pendahuluan}

Fenomena pria metroseksual semakin marak di Kota Tangerang, bukan hanya dalam konteks bahwa pasar kosmetik wanita yang sudah hampir mencapai titik jenuh, namun keharusan bahwa kaum metroseksual butuh sesuatu yang spesial menjelaskan identitas dirinya bahwa mereka tidak ingin memakai produk perawatan yang sama dengan 
wanita. Tinggi $180 \mathrm{~cm}$ dan berat $70 \mathrm{~kg}$ adalah postur yang pas bagi para pria metroseksual. Umumnya mereka memiliki sifat yang romantis, realistis, loyal, open minded dan easy going. Mereka adalah pekerja keras tapi tidak melupakan kesenangan hidup. (Kaum) metroseksual adalah " a dandyish narcissist in love with not only himself, but his urban lifestyle" (Mark Simpson, 1994 dalam Asharfillah, 2010: 75).

Pria metroseksual lebih dari sekedar fakta melainkan juga sebuah fenomena yang kian menggejala dihampir semua kota besar di Indonesia. Perempuan tidak lagi dianggap sebagai ratu kecantikan, pria yang hidup di kota-kota besar mulai menyukai pakaian keluaran butik terkemuka yang harganya minimal ratusan ribu. Pria mulai menyukai keluarmasuk salon sekedar untuk manicure atau pedicure dan mulai terbiasa berlama-lama saat berbelanja sekedar untuk mengetahui produk keluaran terbaru yang dibuat untuk mereka, merekalah pria metroseksual. (Asharfillah, 2010:42).

Pria metroseksual adalah pria yang women oriented man dan memiliki karakteristik unik seperti narsis dan merawat dirinya bahkan cenderung melebihi kaum wanita. Guna menjaga penampilannya pria metroseksual bisa membeli apa pun yang mereka inginkan untuk memenuhi kebutuhan yang berkaitan dengan pekerjaan dan penampilan (Kartajaya, 2004:16).

Munculnya pria metroseksual ini salah satu penyebabnya adalah karena makin banyak wanita yang bekerja. Kehadiran wanita di tempat kerja yang sebelumnya lebih banyak di dominasi oleh kaum pria tentu menuntut rekan kaum pria nya untuk menjaga penampilan nya misalnya dengan berbusana rapi, bertubuh bugar dan berbau harum" (Kertajaya, 2004).

Gaya hidup metroseksual adalah sebuah wacana yang dimunculkan dan dilambungkan kaum industri dan pemasar global untuk menjajakan produk mereka, karena itu wacana ini tak lebih dari strategi pemasaran belaka (Asharfillah, 2010). Dalam konteks wanita mungkin bukan sesuatu yang dipermasalahkan karena pada dasarnya wanita adalah mahluk pesolek dan bukan sesuatu yang menarik untuk dikupas, namun atas nama kaum pria akan menimbulkan sesuatu persepsi lain yang menimbulkan tanda tanya besar.

Apabila di teliti lebih dalam hal yang menyedihkan bagi pria metroseksual adalah mereka seperti tidak bisa menikmati hidup ini dengan membatasi segala macam hal yang bisa merusak penampilan mereka. Pria metroseksual terobesi dengan penampilan rapih dari ujung kaki hingga rambut, rela mengeluarkan banyak uang agar dapat menjadi seseorang yang mereka inginkan. Bentuk tubuh yang kurang bagus dapat diperbaiki dengan mengikuti fitness di pusat kebugaran, mall, kantor, hingga bank ternama. Objek penelitian ini dilakukan di Bank Central Asia KCU Gading Serpong Tangerang, karena terletak di lokasi yang strategis dan memiliki frontliner yang semakin meningkat dari tahun ke tahun.

Frontliner adalah wajah dan ujung tombak pertama yang dilihat oleh pelanggan. Frontliner membentuk citra dan harus mampu menserasikan antara apa yang harapan dan kenyataan. Mempertemukan kepentingan bersama organisasi atau perusahaan dengan pelanggannya. Dengan keharmonisan tersebut, akan menciptakan pula iklim yang terus menerus positif dalam pengertian kreatif, progresif antara kedua belah pihak. Penempatan staff (frontliner) harus hati-hati, karena para staff inilah yang nantinya menciptakan kesan Impression) bagi seorang konsumen. (Baker, 1999:19).

Fenomena pria metroseksual ini menarik untuk diteliti, karena 
metroseksual merupakan sebuah fenomena sosial yang kini mulai banyak dan tersebar di seluruh kota besar di Indonesia dan masih dipandang sebelah mata oleh sebagian masyarakat. Gaya hidup dapat berupa perilaku konsumtif terhadap pria metroseksual, membentuk identitas diri salah satunya adalah gaya berpakaian atau fashion. Konsep dari interaksi simbolik ini menurut Blummer (1969) juga mengacu kepada 3 aspek yaitu makna (meaning), bahasa (language), pikiran (thought).

Dalam penelitian ini, penulis menggunakan Teori Interaksionisme Simbolik yang dapat memberikan penjabaran yang efektif dan jelas dalam kategori interaksi simbolik. Dalam studistudi sosial terutama dalam disiplin ilmu yang masih mencari bentuk namun dalam aspek ini teori interaksionisme simbolik bisa menjadi bagian dalam dirinya, salah satunya seperti komunikasi (Effendy, 2009:1).

Teori interaksionisme simbolik menilai bahwa tindakan aktor tidak semata-mata dikendalikan oleh pranata sosial yang bersifat eksternal pada diri aktor, tetapi lebih pada pemaknaan yang muncul ketika terjadi atau melalui interaksi berlangsung yang di pada realitanya dikelilingi oleh pranata sosial dan struktur sosial (Umiarso \& Elbadiansyah, 2014:61).

\section{Metode Penelitian}

Metode yang digunakan dalam penelitan ini adalah metode penelitian kualitatif. Penelitian ini bermaksud untuk memahami fenomena tentang apa yang dialami oleh subjek penelitian (Moleong, 2007:6).

Paradigma yang digunakan adalah paradigma konstruktivisme untuk menemukan bagaimana peristiwa atau realitas tersebut di konstruksi dan dengan cara apa konstruksi ini dibentuk. Paradigma konstruktivisme menginterpretasikan bahwa realitas tidak menggambarkan diri individu namun harus disaring melalui cara pandang orang terhadap realitas tersebut. George Kelly menyatakan bahwa manusia mengalami pengalaman serta membedakan kejadian menurut kesamaan dan perbedaannya (Litttejohn \& Foss, 2009:180).

Teknik pengumpulan data yang digunakan peneliti dalam penelitian ini ialah wawancara serta observasi. Penelitian dilakukan pada bulan Juli Tahun 2019.

\section{Hasil dan Pembahasan}

Awal mulanya metroseksual dikenal di luar negeri saja, namun pada akhirnya mulai memasuki Indonesia, seperti Jakarta, Bandung, Surabaya dan Tangerang yang merupakan kota-kota besar yang banyak memiliki potensi pria metroseksual. Metroseksual awalnya hanya dimiliki oleh kalangan atas saja, akan tetapi pada kenyataannya dapat dilihat bahwa potensi pria metroseksual tidak hanya dimiliki oleh atas ataupun selebritis saja.

Metroseksual adalah sebuah evolusi kata dan telah menjadi istilah yang dikenal banyak orang. Tidak hanya bagi orang-orang yang kepada mereka istilah itu disematkan, tetapi jauh hingga kepada orang-orang yang bangga ketika orang lain menganggap mereka bagian dari kaum metroseksual atau orang-orang yang bagi mereka gaya hidup metroseksual seperti sebuah mimpi besar, jauh melebihi citacita. (Asharfillah, 2010:1).

Menurut Kartajaya (2006:290) ada beberapa karakter yang terdapat pada pria metroseksual, yaitu : 1) Lebih menikmati suasana belanja sebagai rekreasi (pleasure shopping) daripada belanja karena memang ingin ada yang dibeli (purpose shopping). 2) Memiliki kemampuan komunikasi an interpersonal yang baik dengan orang lain. 3) Lebih senang mengobrol dibanding rata-rata pria lainnya. 4) Dikelilingi oleh banyak teman wanita. 5) Seorang yang introspektif, mau 
berkomunikasi dengan dirinya sendiri. 6) Memancarkan sosok sensualitas yang lembut, baik terhadap wanita maupun pria lain.

Ciri Metroseksual adalah laki-laki muda dengan uang yang banyak untuk dibelanjakan, tinggal dan berada di dalam jangkauan hidup metropolitan karena di sana banyak terdapat di mall, komunitas, gym club, dan salon terbaik. Mungkin saja mereka gay, normal atau biseks. Metroseksual pun menjadi trend dan diterima untuk jangka waktu yang lama. Bagi kalangan seleb, menjadi metroseksual akan memperkuat kedudukan mereka di dunia show-biz karena pencitraan adalah nilai jual mereka. Bagi kalangan berduit, menjadi metroseksual adalah tentang menjadi pusat perhatian banyak orang. (Asharfillah, 2010:30).

Frontliner kini perlahan sudah memiliki potensi metroseksual. Dari penampilan itulah muncul sebuah komunikasi yang dinamakan interaksi simbolik. Melalui interaksi simbolik inilah pria metroseksual ingin menunjukkan maksud dan tujuannya dalam berpenampilan. Melalui penampilannya, wewangian yang dikenakannya dan kebersihan yang terdapat di dalam dirinya memiliki suatu informasi.

Perspektif interaksionisme simbolik memulainya dengan pemaknaan (meaning), bahasa (language), dan pikiran (thought). Premis ini nantinya mengantarkan kepada konsep 'diri' seseorang dan sosialiasainya kepada 'komunitas' yang lebih besar yaitu masyarakat. Menurut (Mulyana, 2008:68) suatu aktifitas yang merupakan ciri khas manusia, yakni komunikasi dan pertukaran simbol yang diberi makna. Konsep diri merupakan gambaran yang bersifat individu dan sangat pribadi, dinamis dan evaluatif yang masingmasing orang mengembangkannya di dalam transaksi-transaksi dengan lingkungan kejiwaannya dan yang dia bawa di dalam perjalanan hidupnya. Konsep diri adalah suatu gambaran campuran dari apa yang kita pikirkan, pendapat orang mengenai diri kita dan seperti apa diri yang kita inginkan.

Konsep diri yang dimiliki oleh pria metroseksual pada sosok frontliner dikatakan baik karena mereka memahami betul dan sangat mengenal dirinya. Pria metroseksual adalah pria yang sangat memperhatikan sekali penampilannya akan tetapi mereka tidak melupakan bahwa diri mereka adalah laki-laki sejati. Pria metroseksual pada sosok frontliner memiliki konsep dirinya sendiri. Pria metroseksual pada sosok frontliner memiliki konsep diri yang membedakan dirinya dengan orang lain, yang membedakan disini adalah dalam hal berpenampilan.

Konsep diri yang ada pada diri pria metroseksual pada sosok frontliner adalah adanya suatu harapan. Harapan-harapan berupa tanggapan dari dalam diri dan tanggapan dari orang lain mengenai penampilan dirinya. Pria metroseksual menginginkan adanya rasa percaya diri ketika mereka berpenampilan seperti itu dan harapan yang positif dari masyarakat sekitar melalui penampilannya. Walaupun penampilannya sedikit berlebihan namun mereka tetap ingin diangap sebagai pria yang mencintai wanita dan menyayangi wanita sama seperti menyayangi dirinya sendiri dan bukan homoseksual.

Emosional pria metroseksual pada sosok frontliner juga memiliki emosional berupa kecemasan akan tanggapan yang sifatnya negatif dari lingkungan sosial yang melihat cara mereka berpenampilan. Kecemasan itu selalu dihilangkan dan merasa tidak perlu mendengar tanggapan orang lain tentang dirinya.

Penghargaan atas dirinya juga turut serta dalam konsep diri seseorang. Begitupula dengan pria metroseksual pada sosok frontliner ini, menurut pengakuan informan, masyarakat menilai pria 
metroseksual dengan positif. Dari penilaian masyarakat tersebut pada akhirnya menumbuhkan rasa percaya diri dan membuat pria metroseksual pada sosok frontliner memiliki harga diri yang tinggi di lingkungannya.

Setiap individu dalam berkomunikasi pasti mengharapkan tujuan dari komunikas itu sendiri, secara umum tujuan berkomunikasi adalah mengharapkan adanya umpan yang diberikan oleh lawan bicara kita serta semua pesan yang kita sampaikan dapat diterima dengan baik oleh lawan bicara dan adanya efek yang terjadi setelah melakukan komunikasi tersebut. Jadi secara singkat dapat dikatakan tujuan komunikasi itu adalah mengharapkan pengertian, dukungan, gagasan dan tindakan.

Pria metroseksual pada sosok frontliner pasti melakukan aktifitas berkomunikasi dalam kesehariannya. Diakui oleh pria metroseksual pada sosok frontliner BCA Tangerang mereka tidak memiliki atau mempergunakan bahasa khusus yang di peruntukkan oleh komunitas pria metroseksual. Bukan hanya dari pendapat pribadi masingmasing pria metroseksual pada sosok frontliner, namun hasil yang sudah diamati tidak ada dan tidak ditemukannya penggunaan bahasa khusus atau bahasa tertentu yang dipergunakan oleh pria metroseksual.

Proses komunikasi yang dilakukan oleh pria metroseksual pada sosok frontliner ini menggunakan bahasa (komunikasi verbal) dan isyarat, sikap tubuh, bahasa tubuh (komunikasi non verbal).

Bahasa yang digunakan dalam setiap komunikasi adalah bahasa yang santai namun tidak kasar. Kelembutan dalam menggunakan bahasa juga diterapkan oleh pria metroseksual pada sosok frontliner. Bahasa disesuaikan oleh pria metroseksual pada sosok frontliner dalam berhadapan dengan nasabah. Maksudnya adalah supaya apa yang disampaikan (pesan) oleh pria metroseksual pada sosok frontliner (komunikator) dapat diterima dengan baik oleh komunikannya (nasabah) sehingga menimbulkan feedback atau umpan balik.

Begitu pula dengan komunikasi non verbalnya, pria metroseksual pada sosok frontliner menggunakan bahasa tubuh, gesture isyarat dan posisi tubuh dalam berkomunikasi. Menggunakan isyarat sebagai bentuk komunikasi non verbal dari pria metroseksual pada sosok frontliner dengan lingkungan sosialnya. Memiliki isyarat bahwa mereka adalah pria sejati, melalui penampilannya mereka isyaratkan. Penampilan yang tidak melupakan sisi maskulin dari seorang pria sejati. Sebagai seorang pria sejati, komunikasi non verbal pria metroseksual pada frontliner juga menunjukan bahwa mereka adalah lelaki sejati. Seperti yang diperoleh melalui hasil wawancara dan observasi langsung, pria metroseksual menggunakan bahasa tubuh yang maskulin dan tidak "melambai" dengan begitu lingkungan sosial pun dapat membaca dan menangkap apa yang terdapat didalam bahasa tubuh pria metroseksual pada sosok frontliner Bank BCA Tangerang.

Posisi tubuh merupakan hal yang kecil namun penting dalam komunikasi non verbal. Pria metroseksual pada sosok frontliner memperhatikan posisi tubuhnya ketika berada dilingkungan sosialnya, baik disaat bekerja dan berada bersama temantemannya. Penggunaan posisi tubuh yang baik sudah dipastikan akan mendapatkan tanggapan yang baik juga dari lingkungan sosialnya.

Dari keseluruhan unsur proses komunikasi dapat dikatakan bahwa pria metroseksual pada sosok frontliner memiliki proses komunikasi dengan menggunakan komunikasi verbal dan non verbalnya dengan memperhatikan etika dalam berkomunikasi sehingga pesan 
yang disampaikan oleh komunikator dapat diterima oleh komunikannya.

Pria metroseksual sebagai individu (manusia) pasti memiliki kepribadian. Kepribadian adalah keseluruhan karakteristik dan penampilan anda yang membedakan anda dari orang lain, pakaian yang dikenakan, garis wajah, nada suara, pemikiran-pemikiran, karakter yang telah dikembangkan dengan pemikiran-pemikiran tersebut, semuanya akan membentuk kepribadian (Hill, 2010: 3). Kepribadian secara umum bisa diambil gambaran seperti kepribadian yang baik dan kepribadian yang kurang baik. Bisa juga dengan kepribadian yang positif dan kepribadian yang negatif. Kepribadian yang di miliki oleh informan adalah kepribadian yang baik dan positif. Dimana setiap informan yang diwawancara oleh peneliti, mereka memiliki aspek-aspek yang terdapat didalam kepribadian.

Sikap sopan, bersahabat dan ramah yang ada pada pria metroseksual pada sosok frontliner membuahkan sebuah citra yang terdapat didalam genggamannya dan orang lain. Pria metroseksual pada sosok frontliner memiliki pendapat, apa yang mereka tampilkan merupakan yang terbaik dan mereka yakin akan adanya citra di setiap orang yang sekedar melihat atau mengenalnya. Tidak hanya melalui pendapat pribadi saja, hasil analisa di atas pun menunjukan adanya pengakuan dari lingkungan sosialnya bahwa mereka adalah pria yang bersih dan wangi. Dengan tanggapan yang positif tersebut, maka citra positif terdapat pada orang lain.

Pengetahuan termasuk di dalam kepribadian, pengetahuan ini meliputi wawasan yang luas dan selalu mencari informasi. Pria metroseksual pada sosok frontliner Bank BCA KCU Gading Serpong Tangerang memiliki wawasan yang luas. Hasil penelitian yang sudah di analisis menunjukan, mereka mendapatkan wawasan mulai dari lingkungan keluarga, teman dan nasabahnya. Kemajuan teknologi berpengaruh juga bagi mereka untuk mendapatkan informasi. Internet dan sosial media diungkapakan sebagai salah satu media yang paling sering dan paling mudah untuk digunakan dalam mencari informasi.

Keterampilan yang dimiliki pria metroseksual pada sosok frontliner adalah keterampilan yang sifatnya maskulin. Masing-masing informan hampir sama memiliki keterampilan pada bidang olahraga dan travelling. Di akui oleh informan bahwa keterampilan ini tidak harus dari latar belakang pendidikan tertentu tapi juga memang karena keahliannya. Sebagai seorang frontliner mereka memiliki keterampilan dalam berbicara guna menarik nasabah dan membuat nyaman nasabah. Sebagai pria metroseksual pada sosok frontliner, tidak hanya menjual wajah saja tapi mereka memiliki kecerdasan. Baik dibidang akademik maupun non akademik, karena mereka selalu menggunakan nalar dan berfikir secara abstrak. Sikap yang ditunjukan kepada orang lain adalah sikap ramah dan bersahabat kepada siapa pun yang berdekatan dengan mereka. Dirasakan pula oleh informan, mereka sangat bersahabat dan baik sehingga membuat seakan antara peneliti dan informan sudah mengenal lama, tapi pada kenyataanya informan dan peneliti tidak ada yang saling kenal sebelumnya.

Pengendalian diri dalam menanggapi emosi bisa juga melihat bagaimana kepribadian orang itu. Semua manusia memiliki emosional yang berbeda dan cara yang berbeda dalam mengatasi emosional yang bergejolak didalam dirinya. Pria metroseksual pada sosok frontliner hanya manusia biasa yang pasti memiliki emosional. Namun dengan begitu, mereka memiliki cara supaya mereka tidak dikendalikan emosi yaitu mengalihkan emosi ke arah yang positif.

Pria metroseksual dikenal dengan hedonis, namun setelah dilakukan 
penelitian, pria metroseksual pada sosok sales promotion boys memiliki nilai atau keyakinan yang berhubungan dengan masa depannya. Walaupun hanya sedikit, setidaknya mereka sudah mengingat akan masa depannya yang pasti akan dijalaninya dengan cara menabung dan mengatur pola keuangan setiap bulannya.

Pria metroseksual pada sosok frontliner Bank BCA KCU Gading Serpong Tangerang tidak mencari kedudukan didalam hidup bermasyarakat. Mereka tidak terlalu terobsesi akan kedudukan. Ada suatu keinginan, akan tetapi berusaha meraihnya dengan cara yang sehat dan tidak menghalalkan berbagai macam cara. Aspek-aspek dalam kepribadian tersebut diterapkkan oleh pria metroseksual pada sosok frontliner didalam lingkungan sosial dan perkerjaan sehingga orang dapat mengetahui bagaimana kepribadian pria metroseksual pada frontliner BCA KCU Gading Serpong Tangerang, penilaian yang didapati adalah kepribadian yang di dimiliki oleh seorang lelaki dan sangat diatur.

\section{Kesimpulan}

Pria Metroseksual pada sosok frontliner Bank Central Asia KCU Gading Serpong Tangerang memiliki konsep dirinya sendiri yang membedakan dirinya dengan orang lain. Konsep diri pria metroseksual pada sosok frontliner Bank Central Asia KCU Gading Serpong Tangerang sesuai dengan harapan dan keinginan mereka sendiri, mereka mengenali betul dan paham betul dengan dirinya sendiri.

Interaksi Simbolik pria metroseksual pada sosok frontliner terlihat dari bagaimana mereka dalam berpenampilan. Pria metroseksual pada sosok frontliner Bank Central Asia KCU Gading Serpong Tangerang ingin menunjukan kepada lingkungan sekitarnya bahwa seorang pria metroseksual adalah sebuah pribadi menarik. Melalui penampilannya, mereka ingin menyampaikan bahwa mereka ingin membuat siapapun yang melihat mereka merasa nyaman dan juga nyaman apabila berdekatan dengan mereka. Apa yang mereka miliki dan apa yang mereka tunjukan dengan simbol- simbolnya, ingin endapatkan sebuah pengakuan dan penghargaan dari lingkungan sosialnya.

Pria Metroseksual pada sosok frontliner Bank Central Asia CU Gading Serpong Tangerang melakukan proses komunikasinya yang sangat memperhatikan etika dalam berkomunikasi. Pria metroseksual pada sosok frontliner Bank Central Asia CU Gading Serpong Tangerang menggunakan bahasa yang tepat dalam berkomunikasi dengan lingkungan sosial dan nasabahnya. Bahasa yang digunakan juga melihat lawan bicaranya, agar pesan yang disampaikan dapat diterima oleh lawan bicaranya.

Pria Metroseksual pada sosok frontliner juga menggunakan komunikasi verbalnya dengan tepat mulai dari bahasa tubuh, posisi tubuh, isyarat dan baubauan. Dengan begitu, lingkungan sekitar dapat dengan mudah memahami apa saja yang disampaikan oleh pria metroseksual pada sosok frontliner Bank Central Asia KCU Gading Serpong Tangerang dan timbal balik (feedback) yang diterima pun bersifat positif.

Pria metroseksual pada sosok frontliner Bank Central Asia KCUGading Serpong Tangerang memiliki kepribadian yang sangat diatur, terlihat dari awal bagaimana seorang pria metroseksual pada sosok frontliner Bank Central Asia KCUGading Serpong Tangerang itu dalam berpenampilan. Penampilan adalah sesuatu yang dapat terlihat langsung oleh mata orang lain.

Dari pengelihatan orang lain, akan tergambarkan bagaimana kepribadian orang tersebut. Walaupun sebagai pria yang menunjukan sisi femininnya, pria 
metroseksual tetap seorang pria yang lekat pada dunianya. Keterampilan dan hobi yang dimiliki tidak jauh berbeda dengan pria lainnya. Kepribadian pria metroseksual pada sosok frontliner dinilai kepribadian yang tangguh, kepribadian yang maskulin namun lembut dan sangat berperasaan.

\section{Daftar Pustaka}

Asharfillah, Zenan. 2010. Metroseksual Korban Kapitalisme Global. Jakarta : Zikrul Hakim Anggota IKAPI.

Cangara, Hafied. 2011. Pengantar Ilmu Komunikasi. Cetakan ke-12. Jakarta: PT Raja Grafindo Persada.

Elbadiansyah \& Umiarso. 2014. Interaksionisme Simbolik dari Era Klasik hingga modern. Jakarta: PT Raja Grafindo Persada.

Effendy, Onong Uchjana. 2009. Ilmu Komunikasi: Teori dan Praktek. Bandung: Remaja Rosdakarya.

Hill, Napoleon. 2010. Hukum Sukses Tentang Memelihara Kepribadian Yang Menarik dan Pemikiran Yang Tepat. Ciputat: Kharisma Publishing Group.

Kartajaya, Hermawan.2003. Marketing in Venus. Jakarta : PT Gramedia Pustaka Utama

Moleong, Lexy J.2005. Metode Penelitian Kualitatif. Bandung : PT Remaja Rosdakarya.

Mulyana, Deddy dan Solatun. 2007. Metode Penelitian Komunikasi. Bandung : PT. Remaja Rosdakarya

Ruslan, Rosady.2004. Metode Penelitian : Public Relations dan Komunikasi. Jakarta: Raja Grafindo Persada.

Tohirin. 2012. Metode Penelitian Kualitatif dalam Pendidikan dan Bimbingan Konseling. Jakarta: PT Raja Grafindo Persada.
Littlejohn, Stephen W. and Karen A. Foss, 2013. Teori Komunikasi Edisi 9. Jakarta: Salemba Humanika 